Prepared in cooperation with the Connecticut Department of Environmental Protection and the Connecticut Department of Transportation

\title{
Streamstats: U.S. Geological Survey Web Application for Streamflow Statistics for Connecticut
}

\author{
By Elizabeth A. Ahearn, Kernell G. Ries III, and Peter A. Steeves
}

\section{Introduction}

An important mission of the U. S. Geological Survey (USGS) is to provide information on streamflow in the Nation's rivers. Streamflow statistics are used by water managers, engineers, scientists, and others to protect people and property during floods and droughts, and to manage land, water, and biological resources. Common uses for streamflow statistics include dam, bridge, and culvert design; water-supply planning and management; water-use appropriations and permitting; wastewater and industrial discharge permitting; hydropower-facility design and regulation; and flood-plain mapping for establishing flood-insurance rates and land-use zones.

In an effort to improve access to published streamflow statistics, and to make the process of computing streamflow sta-

StreamStats is a GIS-based Web application for serving previously published streamflow statistics and basin characteristics for USGS data-collection stations, and for computing streamflow statistics and basin characteristics for ungaged stream sites.

tistics for ungaged stream sites easier, more accurate, and more consistent, the USGS and the Environmental Systems Research Institute, Inc. (ESRI) developed StreamStats (Ries and others, 2004).

StreamStats is a Geographic Information System (GIS)-based Web application for serving previously published streamflow statistics and basin characteristics for USGS data-collection stations, and computing streamflow statistics and basin characteristics for ungaged stream sites. The USGS, in cooperation with the Connecticut Department of Environmental Protection and the Connecticut Department of Transportation, has implemented StreamStats for Connecticut.

\section{StreamStats User Interface}

StreamStats consists of (1) a user interface (fig. 1) that displays maps and allows users to select stream locations for which they want streamflow statistics, (2) a database (StreamStatsDB) that contains previously published streamflow statistics and

The StreamStats website provides detailed documentation, definitions of the streamflow statistics and basin characteristics, and instructions for using the application for Connecticut at (http:// water.usgs.gov/osw/streamstats/ connecticut.html

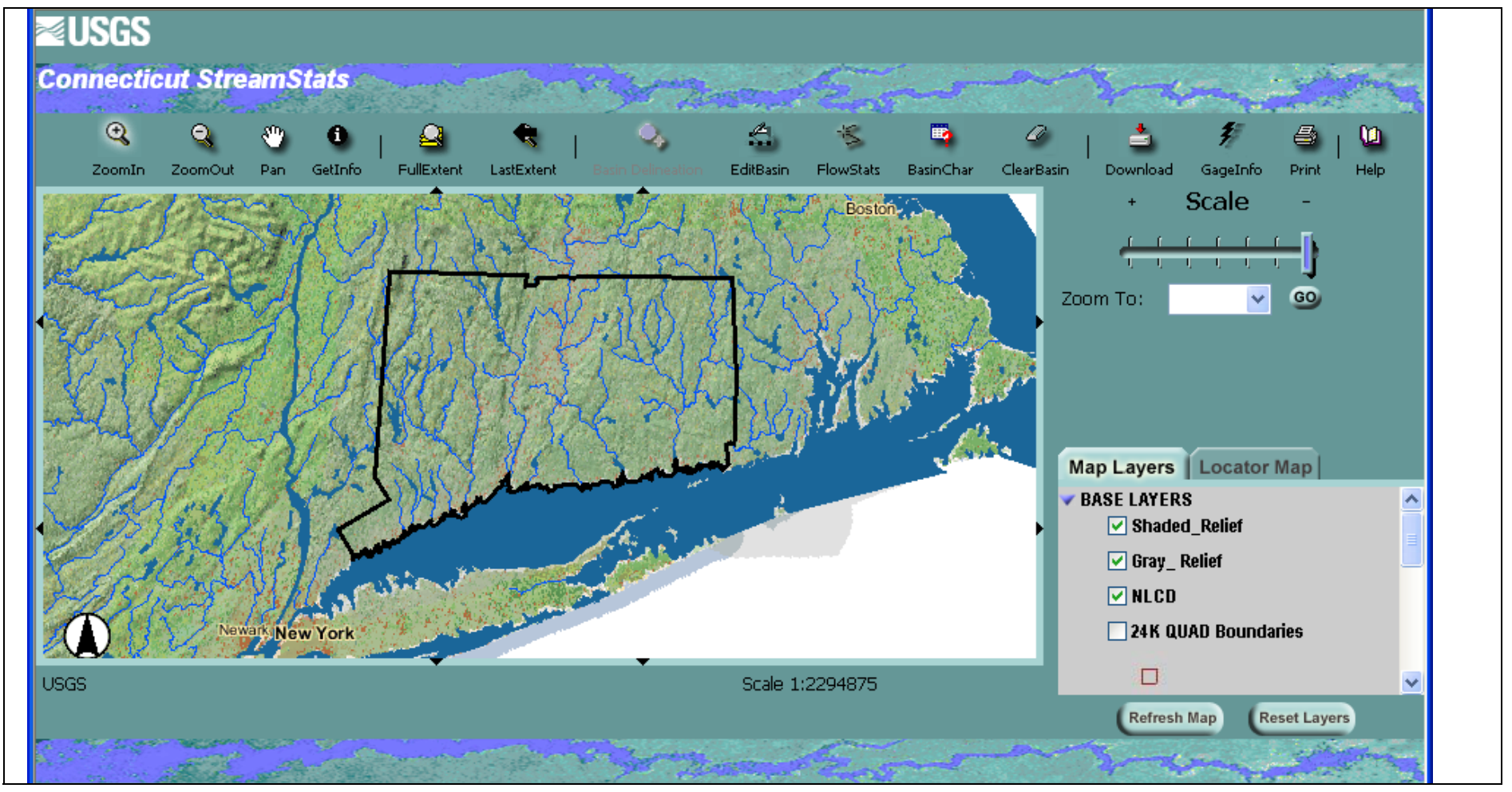

Figure 1. View of the StreamStats user interface zoomed into Connecticut. 
descriptive information for USGS datacollection stations, (3) an automated GIS process that determines drainage boundaries and basin characteristics for userselected ungaged stream sites, (4) a geographic database (geodatabase) that stores base-map data, and (5) an automated process that uses the computed basin characteristics to solve regression equations for estimating selected streamflow statistics.

The StreamStats user interface lets users choose locations of interest from an interactive map and obtain information for these locations. If a USGS data-collection station is selected, StreamStats will provide published streamflow statistics and basin characteristics for that station from the StreamStats database. If an ungaged stream site is selected, a GIS-based process determines the boundary of the drainage basin above the site, computes basin characteristics, and solves regression equations for estimating streamflow statistics. The computed basin characteristics, streamflow statistics, and a map of the basin boundary with the basin characteristics embedded as attributes are provided in the StreamStats output. Citations for reports containing the published statistics, basin characteristics, and regression equations, if applicable, also are provided in the output.

The StreamStats Map Frame displays default and user-selected map layers. The Map Layers Frame, located to the right of the Map Frame, shows the content layers that can be displayed on the Map Frame. Content layers can be turned on or off as desired. A "Zoom To" pull-down menu above the Map Layers Frame facilitates zooming to a user-specified town or city, water feature, or a specified latitude and longitude. A series of buttons above the Map Frame allow navigation within the map by zooming in and out, panning, or returning to a previous or original map extent. Other buttons above the Map Frame provide additional options, such as allowing the user to delineate or clear drainage boundaries, print the views shown in the Map Frame, or retrieve information from the National Water Information System Web (NWISWeb) database (http://waterdata.usgs.gov), a national USGS database that contains information for all data-collection stations.

\section{Streamflow Statistics and Basin Characteristics at USGS Data-Collection Stations}

Currently (2006), StreamStats can be used to obtain previously published streamflow statistics and (or) basin characteristics for about 210 USGS data-collection stations in Connecticut. These stations may be streamflow-gaging stations, where streamflow data are collected continuously; partial-record stations, where streamflow measurements are collected intermittently (usually to estimate peakor low-flow statistics); or miscellaneousrecord sites, where streamflow measurements are collected for hydrologic studies with specific objectives. The output from StreamStats contains descriptive information, and published streamflow statistics and basin characteristics for these stations (fig. 2).

Descriptive information for a data-collection station includes station identification number, station name, station type, period of record, latitude and longitude, hydrologic unit code, major drainage basin name, county name, directions to the station, and remarks indicating any significant effects of human activities on streamflow in the basin.

The StreamStats database currently (2006) contains data for 44 streamflow statistics and 13 basin characteristics for stations in Connecticut. Values for all streamflow statistics and basin characteristics may not be available for each station. Published streamflow statistics in the database are

(1) annual and monthly mean flow statistics;

(2) general flow statistics (minimum, maximum, and average daily flow); (3) flow-duration statistics for the 1- to 99percent flow duration; (4) base-flow statistics; and (5) peak-flow statistics for recurrence intervals of 1.5- to 500-years (annualexceedance probabilities of 0.67 to 0.002 , respectively). Peak-flow statistics are available for stations with 10 of more years of record (as of 2001) that had no substantial effects of flood control or urbanization (Ahearn, 2004).

All USGS data-collection stations in the StreamStats database have information on one basin characteristic: drainage area. For selected stations, the database contains values for as many as 13 additional basin characteristics: mean basin elevation and the 24-hour duration rainfall for the 2-, 10-, 25-, 50-, and 100-year recurrence interval, main-channel length; main-channel slope; maximum basin elevation; minimum basin elevation; relief (difference between maximum and minimum basin elevation); mean annual precipitation (1961-1990); percent area of wetland; storage (percent area of lakes, ponds, reservoirs, and wetlands in a basin); total length of streams; and a basin shape factor (main channel length squared divided by the drainage area).
StreamStats Data-Collection Station Report

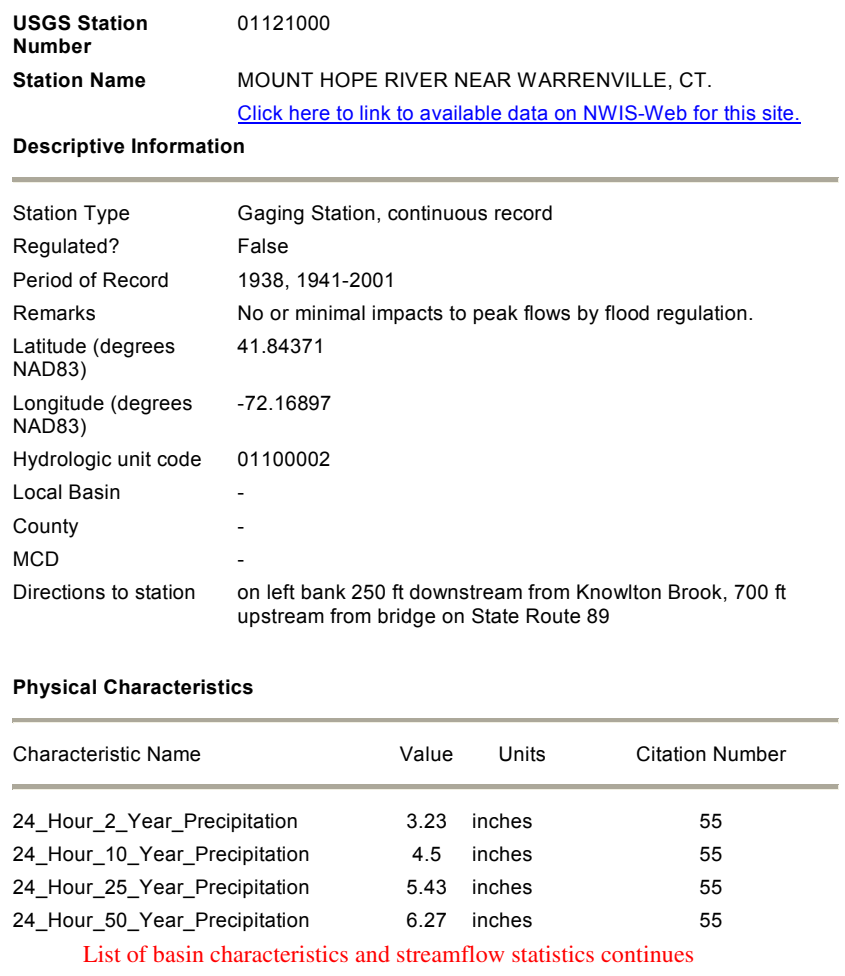

Figure 2. Streamflow statistics report for a data-collection station. 


\section{Streamflow Statistics and Basin Characteristics at Ungaged Stream Sites}

Currently (2006), StreamStats can be used to compute only the peak-flow statistics for ungaged stream sites in Connecticut. The peak-flow equations in StreamStats were derived by regression analysis (fig. 3), which statistically relates the streamflow statistics for a group of datacollection stations to the basin characteristics (Ahearn, 2004). The computed streamflow statistics (2-, 10-, 25-, 50-, 100-, and 500-year peak flows), basin characteristics, and prediction errors associated with the computed streamflow statistics are displayed in a pop-up Webbrowser window (fig. 4) for printing.

Determination of drainage area (fig. 5) is a critical step in solving the peak-flow equations. StreamStats uses an automated GIS process to determine drainage basin boundaries from a digital representation of the stream network, a geospatial data set of predetermined drainage boundaries, and a (30-meter) Digital Elevation Model (DEM), which is a regularly spaced grid of elevation values. The drainage boundary for a stream site is determined by using the DEM to define the boundary up to the point at which the new boundary intersects with previously determined boundaries (Connecticut Dept. of

$$
\begin{aligned}
& Q_{2}=0.329(D A)^{0.769}(P 2)^{2.947}(E L)^{0.262} \\
& Q_{10}=0.510(D A)^{0.776}(P 10)^{2.485}(E L)^{0.260} \\
& Q_{25}=0.947(D A)^{0.784}(P 25)^{2.064}(E L)^{0.243} \\
& Q_{50}=1.37(D A)^{0.790}(P 50)^{1.826}(E L)^{0.235} \\
& Q_{100}=1.86(D A)^{0.799}(P 100)^{1.628}(E L)^{0.231} \\
& Q_{500}=107(D A)^{0.790}(E l)^{0.204}
\end{aligned}
$$

where

$Q_{x}$ is the peak flow for selected recurrence intervals, in cubic feet per second;

$D A$ is the drainage area, in square miles;

$P_{x}$ is the x-year, 24-hour rainfall, in inches; and

$E L$ is the mean basin elevation, in feet.

Figure 3. Regression equations for computing peak flows for the 2-, 10-, 25-, 50-, 100-, and 500-year recurrence intervals at ungaged stream sites in Connecticut.

(From Ahearn, 2004, table 4.)

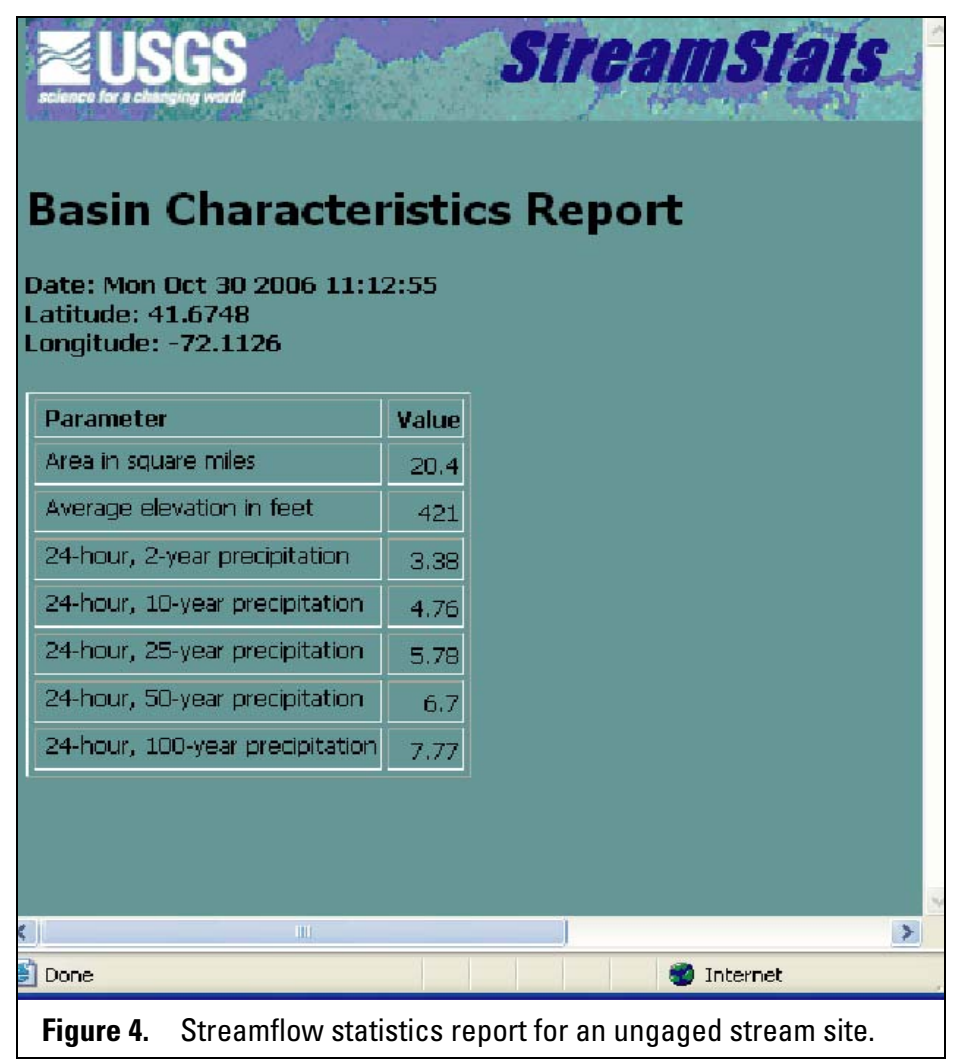

\section{Applicability and Limitations of Regression Equations in StreamStats}

The regression equations in StreamStats that are used to compute peak flow at ungaged stream sites are subject to the same applications and limitations as those described in the original peak-flow report (Ahearn, 2004). The equations should not be used for basins in which flood-control and other manmade structures may substantially reduce peak flows. This is because the equations do not account for detention storage, which is used to reduce peak flows, or for reservoirs, where flow is controlled.

For basins with characteristics that are outside the range of values used to develop the regression equations and for basins that extend outside the state boundaries, peak flows are extrapolated, and warning messages are provided with the StreamStats output. The ranges of basin characteristics used in the original regression study are provided in the StreamStats output, and the user is warned if a variable value exceeds the range. Users are further cautioned that the standard errors in the peak-flow statistics can be larger than the 


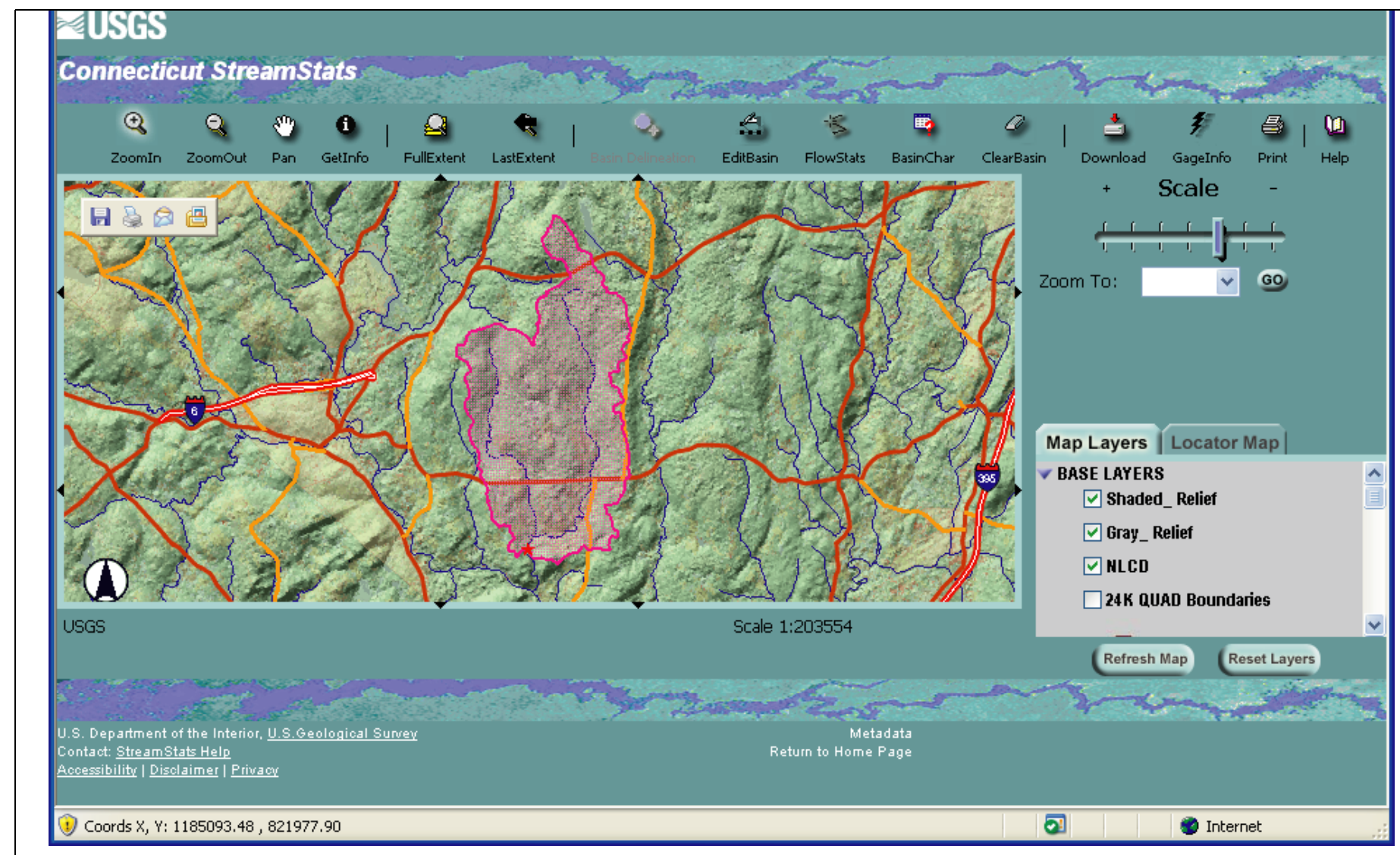

Figure 5. Delineation of a drainage basin for an ungaged stream site.

reported errors. Also, when computing peak-flow statistics for basins in two states, users must manually weight the peak-flow statistics based on the percentage of drainage area in each state (Jennings and others, 1994). In addition, StreamStats does not allow the computation of peak-flow statistics for ungaged stream sites on the main stem of the Housatonic and Connecticut Rivers, where the geospatial data for the computing the basin characteristics are incomplete.

It should not be assumed that StreamStats will provide appropriate warnings in all cases (flood-control structures), or that differences between the streamflow statistics reported for a USGS data-collection station and those derived by the regression equations fully and accurately represent the effects of human activity in the basin.

\section{References}

Ahearn, E.A., 2004, Regression equations for estimating flood flows for the 2-, 10-, 25-, 50-, 100-, and 500-year recurrence intervals in Connecticut: U.S. Geological Survey Scientific Investigations Report 2004-5160, $62 \mathrm{p}$.

Connecticut Department of Environmental Protection, 1995, Drainage basins digital dataset.

Jennings, M.E., Thomas, W.O., and Riggs, H.C., 1994, Nationwide summary of U.S. Geological Survey regional regression equations for estimating magnitude and frequency of floods for ungaged sites, 1993: U.S. Geological Survey Water-Resources Investigations Report 94-4002, 196 p.

Ries, K.G. III, Steeves, P.A., Coles, J.D., Rea, A.H., Stewart, D.W., 2004, StreamStats: A U.S. Geological Survey web application for stream information: U.S. Geological Survey Fact Sheet 2004-3115, 4 p.

\section{Additional Information}

For further information, please contact:

Director

USGS Connecticut Water Science Center 101 Pitkin St.

East Hartford, CT 06108

http://ct.water.usgs.gov

(860) 291-6740

or visit the USGS Office of Surface Water StreamStats Program homepage at: http://water.usgs.gov/osw/programs/ streamstats.html

The use of trade, product, or firm names in this report is for descriptive purposes only and does not imply endorsement by the U.S. Government. 